\title{
Entrevista
}

\section{O Juiz e sua Sociologia: entrevista com Antoine Garapon}

\author{
Fernando de Castro Fontainha* \\ Ana Maria Macedo Correa**
}

Uma das maiores referências francófonas da atual Sociologia do Direito no Brasil é, sem dúvida, Antoine Garapon. Esta entrevista é fruto de uma longa conversa realizada em Paris, em abril de 2013, entre ele e o primeiro autor. A proposta consistia justamente na produção de uma fonte que desse aos seus leitores em língua portuguesa importantes chaves biobibliográficas para uma melhor compreensão de seus escritos. Não é a primeira vez que Antoine Garapon concede uma entrevista de caráter acadêmico. Ele já fez isto em 2008, para um colega francês, e em 2012, para um colega brasileiro ${ }^{1}$. No entanto, ambas as entrevistas são focadas no discurso do autor sobre seu trabalho intelectual (teorias, influências, abordagens) e sobre fenômenos da atualidade. Aqui, nosso enfoque foi a narrativa do autor sobre sua trajetória, das origens familiares e sociais aos projetos do porvir, passando pela infância, vida escolar, universitária, acadêmica e pela sua carreira na magistratura

* Professor da FGV Direito Rio, pesquisador do CJUS - Centro de Justiça e Sociedade, pesquisador associado do CEPEL - Centre d'Études Politiques de l'Europe Latine e doutor em Ciência Política pela Université de Montpellier. Email: fontainha.fernando@gmail.com

** Tutora da FGV Direito Rio, mestre em Teoria do Direito pela Université Aix-Marseille.

1 Eis as referências: LAURET, Pierre. Entretien avec Antoine Garapon. Sur le droit dans la mondialisation et l'anti-juridisme de la pensée française. Cahiers philosophiques, v. 4, n. 116, p. 121-132, 2008, disponível em: http://www.cairn.info/revue-cahiers-philosophiques-2008-4page-121.htm, e GARCIA, José Carlos. Julgar em um mundo em turbulência: entrevista com Antoine Garapon. Revista da Seção Judiciária do Rio de Janeiro, v. 19, n. 34, p. 283-294, 2012, disponível em: <http://www4.jfrj.jus.br/seer/index.php/revista_sjrj/article/view/384.>. 
francesa. Esperamos trazer detalhes sobre as interações - inclusive com brasileiros - que compuseram a rede de onde o autor fala, escreve e publica. Após sua entusiástica concordância, elaboramos um roteiro biobibliográfico - datas relevantes e publicações - que serviria de guia para a entrevista, no sentido de dar-lhe sua única estruturação planejada: uma narrativa sobre a sua trajetória. Assim, em 17 de julho de 2013, por meio do software Skype, Antoine Garapon nos concedeu uma entrevista de duas horas e vinte e nove minutos, ele da sede parisiense da $\mathrm{ENM}^{2}$, e nós do edifício sede da Fundação Getúlio Vargas. O texto que segue é a entrevista transcrita, conferida e aprovada pelo autor, em seguida traduzida para o português. Os acréscimos são de inteira responsabilidade nossa e encontram-se invariavelmente em nota de rodapé.

Fernando Fontainha - Estamos em 17 de julho, 10h04, agora entrevistando Antoine Garapon. Ele está na de sede do Institut des Hautes Études sur la Justice ${ }^{3}$, em Paris. Nós estamos na Fundação Getúlio Vargas, Escola de Direito, no décimo terceiro andar de nosso edifício-sede. Presentes, eu mesmo, Fernando Fontainha, professorpesquisador da Fundação Getúlio Vargas; Ana Maria Corrêa, assistente de pesquisa e tutora da Faculdade de Direito da Fundação Getúlio Vargas; e nosso entrevistado, Antoine Garapon. Bem, escute, Antoine, eu adoraria começar essa entrevista te pedindo para nos dizer seu nome completo, o nome de seus pais, a sua cidade, a data do seu nascimento e a sua qualificação geral.

Antoine Garapon - Eu nasci em 18 de julho de 1952, em Caen, nos Calvados, na Normandia. A família do meu pai vinha da Argélia e então se estabeleceu perto de Oran. Minha infância foi marcada por uma experiência histórica, que foi aquela da guerra da independência e da expulsão dos franceses da Argélia, da qual minha família fazia parte. Depois, fiz meus estudos secundários em uma instituição religiosa e, aliás, cheguei a Paris com 14 anos. Lá, estudei Direito, primeiramente na

École Nationale de la Magistrature (Escola Nacional da Magistratura). Link: http://www.enmjustice.frl.

3 Instituto de Altos Estudos sobre a Justiça. Link: www.ihej.org. 
Universidade de Sceaux ${ }^{4} 6$ e depois fiz meu doutorado na Universidade Paris $\|{ }^{5}$. Em Paris, fiz um DEA ${ }^{6}$ de Direito Privado Geral e tive três professores, que eram Henri Battifol, Gérard Cornu e Jean Carbonnier. Ao final desse DEA, propus ao Jean Carbonnier fazer uma tese, sob sua orientação, sobre o ritual judiciário. Ele me aceitou e, ao mesmo tempo em que tive meu diploma DEA, fui admitido na Escola Nacional da Magistratura. Eu parti em serviço militar para as Ilhas Maurício, onde pude descobrir as civilizações asiáticas durante os 14 meses que fiquei lá. Depois, eu me consagrei juiz da infância, mas, paralelamente a essa atividade de juiz da infância, a qual exerci durante 12 anos, escrevi uma tese sob a direção de Jean Carbonnier, que abordava o ritual judiciário, "Ensaio sobre as formas simbólicas do Direito".

F. - Perfeitamente. Se você me permite perguntar algumas coisas sobre a trajetória que você acaba de descrever, então, seus pais, eles eram argelinos ou franceses que viviam lá?

A. - Eles eram franceses que viviam lá. Meu pai era um intelectual, um professor da Sorbonne e professor secundarista especialista em literatura francesa. Ele se lançou em uma carreira política com os democratas cristãos, a qual foi interrompida pela Guerra da Argélia.

F. - E ele era professor de literatura?

A. - Professor de literatura, absolutamente.

F. - E a sua mãe?

A. - Minha mãe era artista. Ela era gravurista. Fazia gravuras tão bem quanto litogravuras e publicou um livro de gravuras. Nós expusemos suas obras recentemente após sua morte.

F. - Você me disse que vocês foram a Paris. Você terminou seus estudos secundários em Paris?

Link: www.jm.u-psud.fr

Link: www.u-paris2.fr

DEA (Diplôme d'Études Appronfondies) era a denominação do quinto ano do ensino superior. Após a reforma de Bolonha, em 1999, o DEA foi substituído pelo Master 2. 
A. - Sim, absolutamente.

F. - Então, por que a opção pela faculdade de Direito?

A. - Porque eu pertencia a uma família de literatos. Todos os meus irmãos e o meu pai são literatos, agregados ${ }^{7}$ em literatura. Talvez eu quisesse não somente me distinguir deles, mas ter uma profissão mais ativa, mais voltada ao engajamento social e político e, então, é por isso que escolhi o Direito. Era uma época em que, quando eu comecei o Direito, logo após 1968, o grande tema dos anos 70 era mudar a vida. Era uma espécie de novo programa para a esquerda, que se tratava menos de agir sobre as relações de produção numa perspectiva marxista tradicional, mas se tratava de mudar de vida, uma vida em que, notadamente, apareceu o combate feminista e uma vida política marcada pelas profissões: os médicos engajados, os psiquiatras engajados, os juízes engajados... $\mathrm{E}$, claro, eu pessoalmente nunca fui marxista, nunca fui engajado em movimentos marxistas; eu venho da esquerda cristã, e a essa época era uma esquerda cristã muito terceiro-mundista, uma esquerda que eu acredito que era ancestral do que hoje a gente conhece dos movimentos de ecologia, muito do movimento $\mathrm{ATTAC}^{8}$, da antiglobalização. Então, eram movimentos dos anos 70, muito mais voltados para o mundo e para a alteridade, tanto interna quanto externa, do que aos temas clássicos marxistas, que eram majoritários. Eu nunca fui engajado em um movimento radical, contrariamente a muitas pessoas.

F. - E a sua vida de estudante, ela era particularmente agitada pelos eventos dos anos 70 ? Você fez parte de sindicatos estudantis ${ }^{9}$ ? Como foi a sua vida de estudante de Direito?

7 Os professores agregados (agrégés) são aqueles que passam no concurso nacional para recrutamento de professores (Concours d'Agrégation). Nas universidades, representam o topo da carreira docente nas áreas de Direito, Ciência Política e Medicina. No entanto, o entrevistado se refere àqueles que completam a Escola Normal Superiora (École Normale Supérieure - ENS), tornando-se agregados em disciplinas ligadas às letras e humanidades.

8 ATTAC (Association pour la Taxation des Transactions Financières et pour l'Action Citoyenne) é o acrônimo de uma organização antiglobalização, criada em 1998 na França, cujo objetivo é o controle democrático do mercado e das instituições financeiras.

9 "Syndicat Étudiant" é a expressão homóloga ao nosso "Centro/Diretório/Grêmio Acadêmico" 
A. - Meu cotidiano de estudante de Direito foi marcado por uma adesão ao Partido Socialista, antes do congresso de Épinay ${ }^{10}$, em 1971. Socialista, militante socialista e militante de um sindicato de estudantes que era um sindicato, não... como eu poderia dizer? De esquerda, não era comunista, nós não éramos majoritários. Fui eleito uma vez para a representação na $M N E F^{11}$, mas digamos que eu não era um militante extremamente ativo. Tinha minha carteirinha do Partido Socialista, mas nunca tive responsabilidade sindical fora dessa eleição, que eu creio que foi em 1972.

F. - Você comentou agora mesmo sobre alguns nomes de professores que marcaram particularmente a sua formação. Você poderia repeti-los ou ainda adicionar mais outros?

A. - A faculdade de Sceaux era interessante. Foi uma das primeiras faculdades da periferia de Paris. Ela tinha professores brilhantes. Fui aluno de alguns professores que me marcaram, como Georges Vedel em Direito Público, Catherine Labrusse e Bruno Oppetit em Direito Civil. Eram professores de grande qualidade e não se sentiam os "mandarins", como se dizia à época, isto é, eles não eram professores que dirigiam uma matéria ou que se colocavam como patrões em uma matéria; eles eram, sobretudo, jovens que refletiam. Então, depois, em Paris, para o meu DEA, eu deveria escolher entre um DEA de Direito Privado ou de Direito Público. Eu sempre estudei o Direito Privado. Nunca estudei o Direito Público. Isso é importante, eu sempre me interessei pelo Direito Privado, e não pelo Direito Público. Penso que o Direito mais sólido e mais jurídico, se posso me expressar dessa maneira, é o Direito Privado. O Direito Público é um Direito muito ancorado na política. Ele é muito interessante do ponto de vista intelectual, mas observo que frequentemente, na França, as pessoas que estudam o Direito Público não compreendem uma dimensão essencial, que é aquela da vinculação

\footnotetext{
10 O Congresso de Epinay foi o congresso de unificação dos socialistas e notadamente conhecido pela adesão de François Mitterrand ao Partido Socialista (PS).

11 A MNEF (Mutuelle Nationale des Étudiants de France) ocupava-se do regime de seguridade social e assistência aos estudantes franceses.
} 
do Direito, da alteridade do Direito que se impõe como referência. Para o Direito Público, o Direito aparece mais como uma racionalização da soberania do que verdadeiramente como uma referência exterior.

F. - Perfeito. E para o seu DEA em Direito Privado Geral, o que você trabalhou em sua dissertação? Você foi orientado por qual professor?

A. - Eu escolhi a Sociologia do Direito e fiz minha dissertação sobre o direito da filiação em Marcel Pagnol. Foi um estudo de Direito e literatura. Eu sempre tive e ainda tenho a maior admiração pelo Jean Carbonnier, que foi a opção que eu escolhi. Ele era um professor admirável, porque era um grande jurista de Direito dogmático, de Direito técnico e, ao mesmo tempo, era um verdadeiro intelectual, um intelectual que introduziu a Sociologia do Direito na França e tinha, como eu diria, um background, que era seu protestantismo. Eu penso que a atitude de um professor que era ao mesmo tempo jurista e sociólogo e que tinha um ponto de vista um pouco distanciado em relação ao poder da religião majoritária na França, que é o catolicismo, me influenciou muito. Ele era um homem que ensinou a liberdade. Foi um homem que nos ensinou a liberdade de pensamento, e essa dissertação que fiz sobre o direito de filiação em Pagnol traduz a liberdade que Carbonnier nos deixou. Eu tinha assistido às aulas sobre a origem do Código Civil na França e sobre o nascimento do Código Civil, a recepção do Código Civil fora da Europa, e depois um curso sobre o Direito de Família com Gérard Cornu, e depois um curso de Direito Internacional Privado com Henri Batiffol, que foi uma verdadeira alegria, porque eram três grandes almas e três grandes homens, três grandes senhores, que tinham uma riqueza pessoal e espiritual próprias, cada um dos três.

F. - Você se lembra em qual ano você fez o seu DEA?

A. - Sim, eu o fiz em 1976. Defendi minha dissertação em junho de 76. Imediatamente depois, apresentei meu projeto de tese ao Jean Carbonnier e ele aceitou imediatamente. O meu objeto de pesquisa era o ritual judiciário. Por que o ritual judiciário? Porque meu projeto era um pouco inocente, meu projeto era para dizer que quando estamos em uma 
sociedade afastada dos ocidentais, a gente não se interessa quando assistimos, por exemplo, a uma festa... Ou quando as pessoas dançam para fazer chover, ou para garantir a segurança na terra. A gente não se interessa por aqueles que o fazem... A gente se interessa somente por aquilo que vemos objetivamente. A gente descreve os rituais, a maneira como eles estão vestidos, a maneira como eles dançam, os dias consagrados para isso etc. $\mathrm{E}$ eu me disse que deveríamos fazer a mesma coisa com o processo, deveríamos olhar o processo de fora, deveríamos considerar o processo independentemente do Direito. A minha intuição me dizia que deveríamos, sobretudo, olhar o processo, e não deveríamos nos interessar pelo Direito - esse foi meu primeiro postulado. Eu me interessei durante muito tempo na frase de Durkheim que dizia que "os aspectos convencionais das práticas não devem ser jamais presumidos". Durkheim, um autor que me marcou muito e que eu li e depois ensinei na Faculdade de Direito, se interessava pelas realidades sociais, independentemente da consciência dos atores sociais. Então, o meu segundo postulado era dizer que todo mundo considera as formas da justiça, e as formas dos rituais são um folclore. É folclore o fato de os juízes vestirem a beca, dizerem fórmulas preconcebidas, sentarem na sala de audiências. E eu apostei fortemente nessa recomendação de Durkheim, eu fiz a aposta inversa. Eu me disse: "não, devemos fazer exatamente o que se faz na Oceania, na África, e em outros lugares, quer dizer, prestar a maior atenção aos elementos do ritual, e não considerar o que as pessoas pretendem fazer atualmente, que é aplicar o Direito, o que é totalmente secundário". Todo o trabalho foi de desconstituir os elementos do ritual, tentar achar o seu sentido e, então, ler a História do Direito, a Filosofia do Direito ou a Sociologia do Direito, procurando o que foi dito sobre as formas simbólicas do Direito. Esse era o postulado do ritual.

F. - Você se lembra qual foi o ano da defesa da tese que você começou em 77 ?

A. - Sim, foi em 1982, junho de 82. Defendi minha tese diante de uma banca muito prestigiada, pois havia Jean Carbonnier; Pierre 
Bellet, primeiro presidente da Corte de Cassação ${ }^{12}$ da época, que era um homem excelente; havia Michel Villey, professor de Filosofia do Direito; havia François Terré; e, finalmente, Michel Alliot, que ensinava Antropologia do Direito, africanista, em Paris I ${ }^{13}$. Eu defendi essa tese, que recebeu em seguida o prêmio de tese de Paris II do ano de 1982. Foi uma tese que levei seis anos para redigir, a qual fiz paralelamente à minha primeira função de juiz da infância.

F. - Antes de falar do início da sua carreira na magistratura, eu adoraria, se você me permite, perguntar sobre uma curiosidade a respeito do professor Carbonnier. É verdade que ele ministrava seus cursos de Direito Civil de toga e seus cursos de Sociologia do Direito sem toga?

A. - Eu só o vi ensinar Sociologia do Direito, e ele ensinava Sociologia do Direito sem toga. Eu o vi apenas uma vez ensinar de beca, mas era para um concurso de agregação. Eu não posso, absolutamente, certificar esse elemento, mas isso não me surpreenderia. Porém, no dia da minha defesa, creio que ele vestia a beca.

F. - Bem, antes de passar para a magistratura, eu tenho ainda uma pequena questão sobre a sua tese. O livro que você publicou em 95 era a sua tese? "L'âne portant des reliques: essai sur le rituel judiciaire" "4?

A. - Sim, foi a minha tese, e foi em 1985. Foi um livro que eu estava contente de publicar, e foi um livro que não teve nenhum sucesso, a ponto de ser destruído alguns anos mais tarde. Talvez por seu título ser muito enigmático... Mas, na verdade, era efetivamente a edição da minha tese. Depois, eu publiquei o Guardião de Promessas pela editora Odile Jacob, que propôs reeditar o livro sobre o ritual. Eu o republiquei com o novo título, que era mais claro. Se chama Bem julgar e é sobre o ritual judiciário.

F. - Lançado em 1997, não?

\footnotetext{
12 A Cour de Cassation é a mais alta corte da justiça judiciária francesa.

13 Também conhecida como Université Panthéon-Sorbonne. Link: www.univ-paris1.fr

14 "O burro que levava relíquias: ensaio sobre o ritual judiciário"
} 
A. - Isso, em 97.

F. - Nós falaremos um pouco mais tarde sobre algumas obras que você publicou, mas, por enquanto, eu gostaria de te perguntar se era comum, na sua época, ter um magistrado na banca de tese, como no caso da sua tese, que havia o presidente da Corte de Cassação.

A. - Era relativamente raro... Penso que havia muitos magistrados que participavam de teses mais técnicas, mas a minha era um pouco atípica, porque era sobre a Sociologia do Direito e poderia ser um pouco iconoclasta. A primeira vez que ele havia me visto, e que discutimos juntos, ele me teve por um esquerdista. Ele me disse que "pessoas como você não têm nada a fazer na magistratura", que eu deveria partir imediatamente. Ele era um homem um pouco colérico e muito autêntico, muito livre. Depois, quando falei da minha tese, ele ficou apaixonado pelo meu objeto de tese e adotou uma atitude absolutamente inversa. Ele sempre foi muito amigável e nós tivemos uma boa relação até o final da sua vida, aliás.

F. - Então, passando um pouco pela magistratura, você passou no concurso em 1977? Você passou no primeiro concurso?

A. - 1976. Não passei na primeira vez. Não passei em 1975 e me lembro de que tive na prova de Direito Civil o tema sobre "gestão de negócios". Era uma questão muito técnica. Passei no ano seguinte e, então, fui primeiro para as Ilhas Maurício para prestar o serviço militar, e depois entrei na escola da magistratura.

F. - Então, você passou no concurso e, antes de começar a escolarização profissional na ENM, prestou o serviço militar?

A. - É a regra. Não podemos começar uma escola de funcionários públicos antes de prestar o serviço militar. Então, na época, eu tive essa oportunidade de partir para as Ilhas Maurício. Uma oportunidade porque é um país muito bonito, eu me interessava pela Antropologia do Direito e pude assistir aos rituais hindus. Descobri o hinduísmo quando estava nas Ilhas Maurício, que é um país multiconfessional, onde há uma maioria hindu, mas há também há muçulmanos e budistas, notadamente os 
chineses budistas, e, claro, havia também os cristãos, os protestantes e os católicos. Decidi participar praticamente de todas as festas religiosas: hindus, muçulmanas e budistas. Foi para mim um período de formação, de descoberta da alteridade, de descoberta de outra civilização, que me marcou muito nesse aspecto de me interessar pelos rituais.

F. - E depois você foi para Bordeaux para fazer a formação inicial? Como foi a sua formação na ENM?

A. - Para dizer a verdade, eu me sentia um pouco deslocado em Bordeaux, porque já havia passado um ano e meio nas Ilhas Maurício. Trabalhei muito na minha tese em Bordeaux. Li, escrevi e trabalhei muito em Bordeaux. Lá, comecei minha vida ativa e, nesse momento, trabalhei muito na minha tese.

F. - Poderíamos dizer que foi difícil fazer a tese ao mesmo tempo da formação inicial?

A. - Sim, foi duro, e ao mesmo tempo penso que é uma escolha que fiz e da qual não me arrependo, e que continuo a reivindicar. Parece-me que a separação contemporânea entre a academia e a vida ativa ou a vida administrativa não é boa, não me parece desejável, porque isso faz com que tenhamos uma vida acadêmica muito erudita, mas muito distante da realidade, e para mim, a reflexão é algo absolutamente inseparável da experiência direta da existência. Eu constato que os autores que admiro mais são os que tiveram uma vida política. Jurídica, aliás. Penso em Montaigne, Montesquieu, Tocqueville, Hobbes e, finalmente, em Maquiavel. As pessoas que disseram as coisas mais importantes sobre a política e sobre o Direito não eram professores agregados em Direito, não eram professores, eram pessoas que viveram frequentemente por conta própria. Montaigne estava decepcionado com a sua vida política. Ele adorava a política, e acho que sua viagem à América foi uma viagem que ele fez para estudar. Então, parece-me que a experiência da jurisdição, a experiência de juiz, sobretudo para um jovem burguês como eu, de classe média, que era muito protegido... Penso que essa experiência em um gabinete de juiz da infância, na justiça cotidiana, uma justiça extraordinariamente viva e às vezes problemática, foi uma descoberta 
de uma vida de verdade. Creio que isso influenciou fortemente a minha maneira de ver as coisas. Parece-me que a aproximação exclusivamente acadêmica da realidade nos fará passar ao largo das questões mais duras da vida social. Essas questões mais duras são aquelas ligadas à paixão, à violência, àquilo que resiste ao absurdo do comportamento das pessoas. Tudo isso nós vemos quando somos juízes, mas não vemos quando estamos apenas com os livros. Então, para mim, a experiência de juiz da infância foi verdadeiramente uma imersão na vida social. Às vezes, passei por situações extremamente duras. Tive, enquanto juiz da infância, que tomar decisões vinculatórias. Penso que a experiência de juiz confronta a questão do mal. E a questão do mal é incontornável, ou seja, a vida social não é o bem contra o mal, mas sim a experiência, a confrontação direta da maldade, do mal, da violência, da destruição que anima certas pessoas. Por exemplo, quando uma mãe destrói os seus filhos, quando ela percebe a própria descendência, há alguma coisa de incompreensível, de chocante, de profundamente perturbador, mas essa é a realidade da qual devemos partir, parece-me.

F. - Com relação ao mal, você escreveu muito. Eu penso, sobretudo, em obras como A Justiça e o Mal, Kosovo: um drama anunciado, Punir na democracia e Os crimes que não podemos nem punir nem perdoar". Então, o mal é verdadeiramente uma inquietude do magistrado, mas também um objeto de pesquisa?

A. - Sim, absolutamente. Um objeto de pesquisa que encontrei em Ricoeur, uma pessoa que também me marcou muito. O mal é o que há de mais desconfortável de pensar, é o que há de mais desagradável de pensar. É muito mais fácil falar de maneira esclarecida sobre o processo, sobre a deliberação democrática, sobre a troca de argumentos racionais etc. Mas ver os principais problemas da política é saber como gerir, ultrapassar uma coexistência humana que é possivelmente violenta e pode sempre se degradar na guerra civil ou nos crimes de massa. Isso me parece um dado essencial. Quando eu cresci, na Guerra Fria, o mundo era suscetível a uma possível deflagração nuclear, mas o cotidiano da Guerra Fria era razoavelmente pacífico, ao menos na Europa. Havia a Guerra do Vietnã, havia a questão de Cuba, havia a 
questão da África do Sul, mas no fundo a violência era muito contida. Hoje, finalmente, nas democracias do mundo inteiro, nós vemos bem que essa questão de como assegurar conjuntamente as pessoas que são ligadas pela mesma cultura, mas que se detestam e se odeiam a ponto de se matarem, é uma questão central em muitos países e também na Europa.

F. - Eu creio que você tem dois grandes eixos de produção, um sobre a magistratura ela mesma e outro sobre a justiça, a política, o mal, o crime. Mas nós voltaremos a falar disso novamente, se você me permitir. Eu adoraria voltar um pouco para sua carreira. Você falou da sua experiência de juiz da infância no TGI ${ }^{15}$ de Valencienne, que foi de 1980 a 1983, e depois você foi para o TGI de Créteil.
A. - Isso.

F. - Sempre como juiz da infância?

A. - Sempre como juiz da infância. A justiça da infância demanda certa especialização. O que me interessa na justiça da infância é que não é uma justiça técnica, é uma justiça que reclama decisões graves, importantes, que não podem ser justificadas pelo Direito, mas podem talvez ser justificadas por um senso de oportunidade, por considerações sociais, psicológicas, familiares etc. Então, creio que, para ser um bom juiz da infância, é necessário ter vários anos de experiência.

F. - Você foi juiz da infância durante 10 anos, não?

A. - Sim, eu fui juiz da infância durante 10 anos, e se nós adicionarmos dois anos de estágio que fiz notadamente com um juiz da infância, contabilizam-se 12 anos. É uma função que me fascinou, na qual encontrei pessoas formidáveis. Parece-me que na magistratura francesa, e eu estaria prestes a dizer que em todos os países do mundo e em todas as épocas, nós encontramos juízes formidáveis. Nós encontramos juízes servis, muito flexíveis à política, mas nós encontramos também

15 Tribunal de Grande Instance (Tribunal de Grande Instância), homólogo do nosso primeiro grau de jurisdição, abaixo da Cour d'Appel, e esta, da Cour de Cassation. 
pessoas formidáveis. Eu tive a chance de encontrar juízes da infância que me marcaram muito, que me ensinaram da profissão, que tornaram o trabalho de juiz para mim muito atrativo.

F. - Isso foi mais uma escolha sua ou uma necessidade da instituição, o fato de você ter sempre sido juiz da infância? Eles não te propuseram o Parquet ${ }^{16}$ ?

A. - Foi uma escolha, porque, à época (talvez hoje seja menos verdade), era a justiça mais inteligente, a justiça para os menores. Era a justiça que eu podia inovar e lutar, por exemplo, contra o encarceramento dos menores, contra a execução de correções. Nós podíamos lutar para não separar as crianças de sua família em razão da pobreza, então, era uma justiça em que podíamos fazer as coisas, era um laboratório de justiça inteligente. Devíamos ir bem por conta dos menores e por todo o mundo, isto é, uma justiça que se interessa pelos homens, que se revela humanista e mobiliza as ciências sociais. Eu me lembro de que nós estávamos em um momento da década de 80 em que a psicanálise era ainda muito presente e trazia muita esperança de emancipação. Toda a sociedade de então, desde 1968, trazia esse desejo de liberdade, o que não é de maneira alguma a realidade hoje.

F. - E depois desses 10 anos de jurisdição como juiz da infância, você se tornou professor na ENM?

A. - Em 1982, eu defendi a minha tese e Jean Carbonnier e François Terré me pediram para eu pegar o curso do Jean Carbonnier, que era um curso do DEA em Paris II. Então, ensinei Sociologia do Direito durante três anos em Paris II, o que foi muito interessante para mim, porque eu não tinha mais que fazer minha tese, mas deveria falar de grandes autores. Ensinei Max Weber, Durkheim e Bourdieu. Era uma época em que eu tinha uma espécie de dupla carreira: por um lado, profissional da justiça como juiz da infância; por outro, professor convidado, associado, de Sociologia do Direito na Universidade de Paris. Isso durou três

16 Ministério Público, que na França está dentro do corpo da magistratura. 
anos. Depois, infelizmente, isso não pôde continuar, porque eu não era agregado e não tinha o título que deveria ter para continuar. Infelizmente - ou felizmente, aliás, porque isso permitiu que eu fizesse outras coisas - eu tinha essa vida dupla. Então, quando Michel Rocard, em 1990, quis fazer alguma coisa para a justiça, ele quis propor a criação de um instituto que teria por objetivo aproximar a teoria da prática, aproximar o juiz da universidade. E, nesse caso, foi por isso que fui escolhido. Fui escolhido para criar o Institut des Hautes Études sur la Justice, no qual sempre trabalhei, e que é uma aventura humana e intelectual.

F. - Perfeito. Falemos um pouco dessa aventura. Em 1991, em que medida você foi um dos idealizadores do IHEJ? Qual foi a sua contribuição pessoal para o Instituto no início?

A. - No início, foi porque era necessário encontrar o perfil de alguém que conhecesse a realidade judiciária e um pouco de Sociologia e Antropologia. Por isso fui escolhido. Creio que, para continuar com a ideia que desenvolvi agora há pouco, essa separação não deve ser muito marcada, e seria bom que os professores pudessem julgar e os juízes pudessem escrever etc. Então, a ideia desse instituto foi observar, na vida judiciária, todo o movimento, todas as questões novas que são colocadas aos juízes e não são ainda trabalhadas na universidade. A universidade, na França... A Faculdade de Direito sempre esteve atrasada em relação à realidade. Podemos dizer que houve um golpe de sorte, finalmente, para que Michel Rocard criasse o IHEJ, porque foi um momento em que os juízes... Foi logo após a queda do muro de Berlim, um momento em que os juízes estavam mais e mais ativos, e notadamente eles julgavam os políticos por conta dos casos de corrupção. Então, nós notamos que era o início do movimento de "judiciarização"17 da vida política francesa, e poderíamos dizer que da vida democrática em geral, isto é, um movimento no qual víamos os juízes tomarem decisões muito importantes no jogo político da corrupção e em outros casos midiáticos, isto é, os escândalos. Foi no momento em

17 Em português, é admitida a expressão/conceito judicialização ou judiciarização. No original em francês, o termo utilizado pelo entrevistado foi "judiciarisation". 
que nasceu a Justiça Penal Internacional. Então, isso que eu chamei de "judiciarização", ou penalização da vida política, inquietava muitos homens políticos. Nós não compreendíamos ainda verdadeiramente, porque a "judiciarização" não era feita pelos juízes de esquerda, por juízes revolucionários, pelos sindicatos; eram juízes que estavam mais à direita e tinham uma ideologia totalmente nova, que era a ideologia do juiz justiceiro. É um pouco pejorativo de dizer isso... Então, foi, para a França, um movimento muito perturbador.

F. - Você também chamou alguns desses juízes de juízes vermelhos, não?

A. - Não, o juiz vermelho é um pouco diferente. Os juízes vermelhos eram os da geração de 68, era o Sindicato da Magistratura. No sentido do que eu dizia há pouco, eles queriam mudar nossas vidas, queriam mudar a sociedade pela justiça e que a justiça fosse a guardiã da ordem e da moral, uma espécie de modificadora da sociedade, acompanhando a emancipação dos costumes. Entre parênteses, eu constato que isso ainda continua sendo verdadeiro. Quando a gente vê a evolução do Direito de Família, o juiz da família francês não é mais absolutamente o guardião da ordem moral que mantém o modelo da família burguesa, católica, branca, da classe média. Na verdade, o juiz da família francês é muito inovador, que inventou a guarda partilhada, por exemplo. Então, nós percebemos que esse foi um movimento dos anos 70 , dos juízes vermelhos, avançados em relação à sociedade. Mas a categoria dos juízes que virão na década de 1990, que vão estar na operação contra a corrupção na Itália, que vão ser procuradores em Genebra, que vão ser os juízes espanhóis - eles são menos ligados a um modelo de sociedade -, essa será a grande novidade: os políticos são os novos litigantes.

F. - Perfeito. Na temática da "judiciarização" e penalização, foram lançados dois livros em 96: Guardião de promessas e República penalizada. Esses dois livros foram os que marcaram as suas primeiras reflexões no IHEJ, poderíamos dizer?

A. - Sim, absolutamente. Foi o primeiro livro, em que, na verdade... Eu descubro, nesse momento, Durkheim, Weber, Marx, além de, claro, 
Bourdieu. Mas eu descubro também a Filosofia. Chegando ao IHEJ, eu tinha uma pequena cultura filosófica, uma pequena bagagem. Mas lá, eu descubro a Filosofia, e eu a descubro principalmente através do Paul Ricoeur. Ricoeur e a revista Esprit, a qual eu integro desde essa época, me fazem descobrir o movimento antitotalitário, quer dizer, uma filosofia que é marcada por Tocqueville, Gauchet etc. É uma filosofia que pensa a política de maneira totalmente diferente e totalmente nova a partir da experiência do nazismo e do comunismo. O que não é absolutamente o caso da esquerda clássica. Então, houve, nesse momento, toda uma descoberta intelectual dessa escola de pensamento e que, aliás, vai se traduzir em engajamento militante pelos direitos do homem, pela pluralidade, pelo respeito das minorias, contra essa aliança do nacionalcomunismo. Por exemplo, Milosevic era um homem comunista, ligado a essa visão do totalitário e do político, e ao mesmo tempo nacionalista sérvio. Então, para mim, foi nesses anos 90 a descoberta e o engajamento. Creio que os juízes deveriam inventar seu papel, não mais como um ator político sindical, mas deveriam reinventar o seu papel como atores da pluralidade democrática, um ator dos direitos fundamentais, um ator do respeito às minorias e da dignidade humana. Então, eles são completamente diferentes dos juízes vermelhos.

F. - Bem, há o Guardião de promessas e a República penalizada, nos quais nós o vemos pela primeira vez em parceria... Você escreveu a República penalizada com Denis Salas e essa foi sua primeira parceria intelectual. Como você conheceu Denis Salas, que, aliás, se tornou um grande parceiro? Vocês publicaram bastante juntos, não?

A. - Sim. Com o Denis Salas eu tenho uma grande proximidade, pelo fato de nós termos a mesma idade, pelo fato de termos o mesmo trabalho de juiz da infância e depois de intelectuais da justiça, e pelo fato de sermos os dois pied-noirs ${ }^{18}$ da mesma cidade, Oran. Aliás, nós temos a mesma sensibilidade por Albert Camus, que era um grande pied-noir, um grande francês de origem argelina. Então, nós temos muitas coisas em

18 Pied-noir é um termo francês que, em português, quer dizer literalmente "pé negro", para designar os franceses originários da Argélia. 
comum e decidimos escrever juntos. E nós escrevemos, efetivamente, muitas coisas juntos. Eu pratico muito na minha vida a ideia do coletivo intelectual. Não no sentido que entendiam os marxistas, mas no sentido de que as ideias não são uma espécie de prazer narcisista, mas um elemento da construção social, da reforma social, então, é importante partilhar as ideias com os outros. E a experiência de escrever com muitos é sempre uma experiência de confrontação, mesmo com as pessoas que são próximas, e é assim que eu escrevo com o Denis Salas. Nós escrevemos outros livros... Com Papadopoulos, Julgar nos Estados Unidos e na França. ${ }^{19}$ Toda vez, essa aventura intelectual é uma aventura humana.

F. - Depois, há outras publicações. E na virada do século, em 99, você disse que, um pouco por influência de Paul Ricoeur, tornou-se diretor da coleção de Filosofia de Direito, "Bien Commun", pela editora Michalon.

A. - Sim, foi em 95, pela editora Michalon, porque eu digo sempre a mesma coisa. Penso que as ideias são um princípio da ação, são reflexões que devem retornar um dia ao mundo, e há muitos autores insuficientemente conhecidos porque são reservados ao pensamento universitário. Frequentemente, na França, não sei se é assim no Brasil, mas na França existem autores que escrevem teses de 800 páginas sobre a noção de povo em Hobbes, mas nós não temos acesso, em termos simples, ao pensamento desse autor. $\mathrm{E}$ eu constato que, na França, a Filosofia do Direito é pouco desenvolvida se compararmos com a filosofia moral, que é enorme, e com a filosofia política. Então, a ideia dessa coleção era reunir em pequenos livros, fáceis de ler, grandes teses, que nos permitissem entrar numa grande obra, compreender as pessoas que nós escutamos falar, mas não sabemos exatamente o que elas dizem. Foi assim que publicamos o primeiro livro sobre Hannah Arendt. Creio que foi um dos primeiros livros sobre Hannah Arendt, sobre

19 Vale notar uma interessante resenha publicada sobre a tradução deste livro para o português: LOBÃO, Ronaldo. O tempo no Direito: Resenha (Review) de "Julgar nos Estados Unidos e na França: Cultura Jurídica Francesa e Common Law em uma Perspectiva Comparada", de Antoine Garapon e loannis Papadopoulos. Revista Dilemas, v. 1, n. 1, 2008, disponível em: http:// revistadil.dominiotemporario.com/doc/Dilemas1Res.pdf.social 
Ricoeur, mas também de pensadores mais radicais, como Derrida ou Jean Luc Nancy. Isto é, devemos repovoar as bibliotecas dos franceses de Filosofia do Direito.

F. - Você teve outras experiências como essa do comitê de redação da revista Esprit, que se eu não me engano começou em 99.

A. - Eu entrei na Esprit em 90.

F. - E como você poderia descrever essa experiência relativamente longa da animação do programa "Bien Commun", da rádio France Culture?

A. - Então, isso foi em 99, quando Laure Adler me chamou para animar um programa na France Culture que se chama "Bien Commun", e sempre nessa ideia de espaço público, de que as ideias são feitas para serem partilhadas, discutidas, debatidas. Eu animei esse programa na France Culture, que agora faz 15 anos e já teve diversas formas. No início, era aos sábados; depois, às terças, quartas e quintas. Bem, e a cada vez a ideia de que me considero um transmissor que deve transmitir as ideias de um mundo a outro. Sendo um profissional do Direito e participando do meio profissional, conheço as preocupações, as aspirações, as inquietudes, e isso que eu quis fazer: tentei compartilhar essas aspirações, essas inquietudes, a um público maior, um público esclarecido, que é o da France Culture, porque só há transformação social, só há evolução quando um certo número de ideias são compartilhadas com um público maior. Isso não pode ser apenas uma coisa de professores.

F. - Então é uma experiência de interagir mais com pessoas que não são profissionais do Direito ou da academia. Poderíamos dizer "indivíduos ordinários". Foi uma experiência rica, eu suponho.

A. - Ah, certamente. Os juristas vivem muito entre eles e, sobretudo, creem muito na autonomia do Direito. Porém, eu penso que a verdade do Direito encontra-se fora do Direito; a verdade do Direito encontrase nos costumes, nos princípios, na filosofia, em certas aspirações do povo. Elas podem variar, mas me parece que devemos dar substância cultural, política e moral às regras, que são abstratas. Não nos devemos limitar a esse jogo de virtudes extremamente formalistas, extremamente abstratas, que é normalmente a cara do mundo dos juristas na França. 
F. - Se você me permite, nós poderíamos ir direto a 1999, o ano em que você foi pela primeira vez traduzido para o português e publicado no Brasil. Eu falo do Guardião de promessas, que aqui apareceu com o título de O juiz e a democracia: o guardião de promessas. Você poderia nos dizer, se você souber, se você se lembrar, se essa publicação é reflexo direto de alguma relação que começa a se desenvolver com algum colega ou pesquisador brasileiro?

A. - Sim. Encontrei muito cedo o professor Kant de Lima ${ }^{20}$, Roberto Kant, com quem me dei muito bem. Nós compartilhávamos a mesma sensibilidade sobre a realidade, sobre a cultura, sobre o Direito. Ele me enviou textos que havia escrito, notadamente, um texto formidável no qual ele diz que "os índios somos nós" 21 , isto é, quando os brasileiros estão nos Estados Unidos, são eles que se passam por pessoas bizarras. Então, graças a ele pude encontrar muitos intelectuais brasileiros, não muitos, que não eram juristas, mas eram filósofos, etnólogos, antropólogos do Direito.

F. - Bem, ele é prefaciado pelo Paul Ricoeur?

A. - Sim, porque tive a chance de ter uma relação de amizade com o Paul Ricoeur. Foi ele mesmo que pronunciou essa palavra e ele estava contente de ter relações de amizade com jovens. "Eu sou o contemporâneo de meus sucessores", dizia ele. Durante quinze anos, nós nos víamos muito e debatíamos muito, o que era algo formidável no Paul Ricoeur, já que ele era um grande filósofo, mundialmente conhecido. Nós tínhamos discussões de igual para igual e ele jamais lançava argumentos de autoridade, dizendo "Spinoza disse...”. Então, o Paul Ricoeur tinha isso de ser recebido pelos outros, pelos historiadores, pelos literatos, quer dizer, ele tinha todo esse sentimento, embora fosse um guardião, dominava bem a tradição filosófica. Ele tinha o sentimento

\footnotetext{
20 Atualmente, Roberto Kant de Lima é professor adjunto do Departamento de Segurança Pública da Faculdade de Direito da Universidade Federal Fluminense e professor titular aposentado do Departamento de Antropologia da mesma universidade. Currículo Lattes: lattes.cnpq. $\mathrm{br} / 5653459744288495$.

21 KANT DE LIMA, Roberto. "A Antropologia da academia: quando os índios somos nós". Niterói: EdUFF, 1997.
} 
de que a Filosofia deveria ser recebida, dizia ele que o filósofo deveria ser recebido pelos meios não filosóficos.

F. - Bem, se eu entendi bem, foi o professor Kant de Lima que te propôs de ser traduzido no Brasil. Na verdade, ele é um grande difusor das suas obras, das suas ideias no Brasil, da antropologia jurídica no Brasil. Foi a sua ligação com o Kant de Lima que fez com que suas obras fossem publicadas no português do Brasil? Juiz e a democracia, em 99, e Julgar na América e na França, em 2008, foram por intermédio do Kant de Lima?

A. - Sim, certamente. O que me impressionou no Brasil foi o dinamismo. Há duas coisas que são muito preciosas no Brasil. Primeiramente, há uma vida intelectual absolutamente rica, notadamente em antropologia, pois a sociedade brasileira em antropologia é impressionante em dinâmica e riqueza. Em segundo lugar, há uma grande familiaridade intelectual com a França. Encontrei no Brasil, entre os intelectuais brasileiros, uma sensibilidade comum, tanto no Direito como mais amplamente na política. Creio que isso é extremamente precioso, isto é, a espontaneidade como povo latino, como aqueles que compartilham a mesma cultura latina, e talvez católica, não sei. Há uma grande proximidade na troca de ideias.

F. - Enfim, falando de seus parceiros brasileiros, além do Kant de Lima, você tem outros. Você se lembra de outros com quem mantém contato? A. - Ah sim, sim. Com um professor de Brasília, Luis Cardoso, com quem tenho frequentemente contato e com quem tive muitos debates. Tem também o Fábio Reis Mota ${ }^{23}$, que é um jovem pesquisador e passou um tempo na França, e José Carlos da Silva Garcia ${ }^{24}$, que é um juiz federal que veio também ao IHEJ. Também se estabeleceu no IHEJ um certo número de intelectuais brasileiros, homens e mulheres, juristas e não

22 Luis Roberto Cardoso de Oliveira é professor titular no Departamento de Antropologia da Universidade de Brasília. Currículo Lattes: http://lattes.cnpq.br/2935371042756080.

23 Atualmente, professor adjunto do Departamento de Antropologia da Universidade Federal Fluminense. Currículo Lattes: http://lattes.cnpq.br/5620090660136938.

24 Atualmente, é juiz federal no Rio de Janeiro. Currículo Lattes: http://lattes.cnpq. br/0265922799985113. 
juristas. Na maior parte do tempo, são sociólogos. No Brasil, há alguns intelectuais com os quais eu debati muito; são pessoas que têm uma competência jurídica e são verdadeiros intelectuais.

F. - A orelha de seu primeiro livro publicado no Brasil, O juiz e a democracia, foi escrita por um sociólogo brasileiro bem conhecido, Luiz Werneck Vianna ${ }^{25}$. Foi só uma proximidade de interesses ou você conheceu o Luiz Werneck Vianna?

A. - Não, eu não o conheço. O que é interessante na tradução é que você é traduzido e suas ideias circulam sem que te peçam permissão. Então, eu não o conheço e, frequentemente, encontro brasileiros que podem falar de coisas que escrevi, mas que não conheço. Eu encontrei também Jânia Lopes Saldanha ${ }^{26}$, que é uma professora de uma universidade no Sul, eu não sei exatamente. Ah, com o Luis Cardoso, de Brasília, eu tenho estado frequentemente em contato. A gente conversa muito. $E$ há agora esses novos professores franceses no Brasil. Acho que o professor François Deluchet está em Belém, no Norte. No Brasil, há um grande dinamismo, mais do que na França, e há circulação de ideias entre a Antropologia e o Direito.

F. - E você veio ao Brasil algumas vezes, não? Para congressos, palestras?

A. - Exatamente. Eu fui ao Brasil e espero retornar, aliás. É extremamente interessante, porque é um país imenso. Nós não temos mesmo a noção na França dessa importância. É verdadeiramente um continente. É um mundo que goza de uma imagem muito positiva na França, muito amiga. É uma imagem de grande proximidade com a França, com a qual eu posso absolutamente confirmar no plano intelectual.

\footnotetext{
25 Atualmente, professor titular do Departamento de Sociologia da PUC/RJ. Currículo Lattes: http:// lattes.cnpq.br/1944208293448093.

26 Professora associada do Departamento de Direito da Universidade Federal de Santa Maria. Currículo Lattes: http://lattes.cnpq.br/9285450415334580
} 
F. - Então você considera que tem ligações fortes... Se pensar nas suas relações com pesquisadores estrangeiros, não franceses, você acredita que os brasileiros contribuíram muito para...?

A. - Sim. Estou em contato com pesquisadores americanos, muitos anglo-saxões, que são pessoas muito interessantes, mas bastante diferentes. Trabalho também com a China, que é ainda mais diferente. Com o Brasil, é como com os italianos para mim, isto é, são pessoas com as quais eu sinto uma sensibilidade muito próxima, fora a língua. Eu te dou um exemplo: todas às vezes que vou ao Brasil, falo em espanhol. Eu não falo português, infelizmente, mas tenho a impressão de que a gente pode se compreender, pois as maneiras de construir as frases são as mesmas, a maneira de construir as ideias é muito próxima.

F. - Quando veio ao Brasil, você chegou com a tradução e as publicações brasileiras de suas obras. Você foi bastante traduzido para o português, particularmente pelo instituto Piaget da Fundação Calouste Gulbenkian. Eu falo de suas duas obras que apareceram em 2000, Bem julgar e Justiça e o mal, mas também Punir na democracia, em 2002, Os crimes que não podemos perdoar nem punir", em 2004, e, enfim, O juiz na globalização, em 2006. Então, nós diríamos que você tem uma ligação forte com o Instituto, com a editora, ou com Portugal?

A. - Creio que o Instituto Piaget me traduziu uma vez e depois eles traduziram muitos de meus livros. Foi formidável, porque isso me permitiu encontrar muitos pesquisadores portugueses. Mas nós não temos ingerência sobre essas traduções. Trata-se da curiosidade e do interesse da comunicação por esses livros. É uma comunicação silenciosa.

F. - Eles te traduziram pela primeira vez e depois foi uma demanda deles mesmos?

A. - Sim, passou pela minha editora, e eu mesmo não tomei consciência.

F. - Você tem também outras experiências internacionais. Você obteve o título de Doutor Honoris Causa pela Universidade de Liverpool?

A. - Sim, absolutamente. 
F. - Como isso aconteceu?

A. - Porque eu trabalho muito com os ingleses. Com a Inglaterra foi muito engraçado, porque nós somos incrivelmente próximos. Londres é mais perto de Paris do que Lyon, e ao mesmo tempo somos muito diferentes, notadamente na área da justiça. Então, eu tenho ligações próximas com juízes ingleses, mas que são sempre para mim uma espécie de interrogação de como a Common Law funciona, como a justiça inglesa funciona.

F. - Isso foi em que ano exatamente?

A. - Isso começou bem cedo. Tudo isso começou nos anos 90. Na verdade, eu vou regularmente, sobretudo porque na Europa os trajetos são facilitados pelo trem. Com a Eurostar, eu chego em Londres em duas horas, é muito fácil de chegar. Agora, os ingleses têm uma espécie de IHEJ, o Judicial Institute, então frequentemente eu vou encontrar os colegas ingleses.

F. - Somente para estabelecer bem a documentação da sua história, em qual ano você obteve o título de Doutor Honoris Causa?

A. - Foi em 95. Eu havia colaborado muito com a Universidade de Liverpool para enviar jovens franceses, jovens juízes franceses para a jurisdição inglesa. Isso continua depois de muito tempo, e minha relação com Liverpool é por meio do professor Bernard Jackson. Agora, o professor Jackson deixou Liverpool. Então, foi para consagrar e celebrar essa colaboração que eu recebi essa distinção.

F. - Você teve também uma experiência no exterior como Chair Professor no Instituto HiiL ${ }^{27}$, em Haia, onde você ensinou uma nova metodologia de Case Studies? É isso?
A. - É isso.
F. - Como foi essa experiência?

27 The Hague Institute for the Internationalisation of Law (HiiL). Site: http://www.hiil.org/. 
A. - Essa foi mais recente. É sempre a mesma ideia do ritual judiciário, isto é, uma ideia de compreender a justiça através das imagens e através das imagens do processo. Na verdade, a técnica consiste em refinar o processo na França, na América e na China, verdadeiros processos, e depois compará-los, descrever o que vemos com os antropólogos da imagem, para tentar compreender o que são os juízes, o que os advogados têm em mente, quais são as expectativas da justiça. É um novo método que experimentei em um curso que dei com um colega chinês em Haia. Perdão, foi em Maastricht, e depois em Liège, entre 2008 e 2009.

F. - Eu vejo que, ao menos aqui na minha lista, a sua última publicação foi La raison du Moindre État: le néoliberalisme et la justice, em 2010. Foi isso mesmo?

A. - Sim, absolutamente. Ele vai ser traduzido em português e vai ser lançado em breve. Vai ser publicado no Brasil e traduzido por Jânia Lopes Saldanha. É um trabalho de um filósofo que eu tenho descoberto intelectualmente, que é o Michel Foucault, que me parece ser um grande filósofo. Então, trata-se de uma reflexão sobre de que maneira a economia se coloca como um discurso de verdade para tudo, para o Direito notadamente. É uma reflexão que Michel Foucault chama de "gouvernementalité", isto é, não ideologia, mas a maneira de conduzir os homens.

F. - Já que você falou de um projeto para o futuro próximo, você tem outros? Você está trabalhando em um artigo ou um livro? Quais são os seus projetos próximos?

A. - Então, nesse momento, estou fazendo algumas coisas. Tem um livro coletivo que vai ser publicado em 2 ou 3 meses que trata sobre a importância dos Deals, isto é, dos acordos transacionais contra as grandes empresas globalizadas e o departamento de justiça americana, uma técnica utilizada pela administração americana para resolver os conflitos globais, o que me parece uma boa maneira de compreender o Direito global. Depois, vou trabalhar um livro com alguns senhores que 
explicam o Direito Comparado por meio da audiência, com um amigo chinês e um amigo americano.

F. - Com um chinês e um americano?

A. - Exatamente.

F. - Vocês o escreverão, os três?

A. - Sim, é isso. A gente vai refletir junto para ver como nas diferentes sociedades são produzidos os efeitos da verdade, os enunciados da verdade, e a ideia é de que é preciso se compreender junto, e não sucessivamente, mas simultaneamente, para comparar os Estados Unidos, a China e a França.

F. - Muito obrigado de nos avançar seus novos projetos. Escute, se você me permite algumas questões finais, eu vou te pedir para fazer um balanço de seus últimos 20, 30 anos. Um de seus objetos de investigação é a magistratura, uma espécie de ontologia e por que não dizer sociologia profissional da magistratura. Eu falo de Vertus du juge, Les juges dans la mondialisation, Juger en Amérique et en France, Les juges: un pouvoir irresponsable?. Então, você tem muitas reflexões sobre a profissão, sobre a função, sobre o papel dos magistrados no mundo atual. Como os seus colegas da instituição reagem frequentemente às suas ideias e às suas publicações?

A. - No começo, havia um pouco de desconfiança, porque o espírito corporativo rejeita aquilo do qual eles não fazem parte. Então, teve um sentimento de desconfiança, de rejeição, e agora creio que esse sentimento foi apaziguado e os juízes franceses aceitam bem essa função de reflexão na magistratura.

F. - Você já teve problemas particulares, porque, frequentemente, os acadêmicos, os universitários, reivindicam para eles que a instituição universitária lhes garanta uma espécie de independência. Mesmo que você trabalhe em um instituto peculiar, que não é nem mesmo a Escola Nacional da Magistratura, mas no seio de uma instituição judiciária. Você já foi ameaçado, num sentido mais leve. Você já sentiu uma espécie de barreira na independência para publicar ou escrever? 
A. - Sim, sim. Isso aconteceu há alguns anos, notadamente depois do 11 de setembro. O lobby policial na França quis monopolizar a reflexão sobre a justiça, dizendo que a justiça é um órgão de segurança e por isso não precisa de reflexões independentes, é suficiente ter uma função estritamente instrumental sobre o que funciona melhor em termos de reflexões sobre a população. Eu sofri esse ataque há alguns anos por parte do lobby da segurança, principalmente policial, para fechar o IHEJ, mas nós sobrevivemos, graças a Deus.

F. - Graças a Deus? Certamente, eu não quero saber dos detalhes que não podem ser contados, mas graças a Deus e talvez a um contra lobby? Você teve defensores ou pessoas que te apoiaram?

A. - Graças ao apoio de parte da alta magistratura administrativa e constitucional francesa. Eu penso particularmente no Jean-Marc Sauvé, que apoiou o IHEJ, o que me agradou, pois me mostrou que nós servimos para alguma coisa. Eu poderia dizer que houve um apoio, porque finalmente os juízes, que passam o seu tempo a exercer uma profissão que é difícil, que é complicada, se sentiram também atacados... não atacados, mas se sentiram desconsiderados a serem levados para o centro de um órgão de segurança, e por isso houve um amplo processo para proteger o IHEJ.

F. - Com relação à sua posição pessoal de magistrado que não exerce mais a jurisdição, mas tem uma posição particular no seio da magistratura, você disse que no início havia um pouco de desconfiança. Não são raros os magistrados nessa posição?

A. - Creio que há magistrados que largaram a magistratura há tanto tempo quanto eu, mas em geral estão longe da magistratura. Eles fazem política, estão nos negócios ou no ensino. Para mim, o que é um pouco original, é que eu não estou mais na jurisdição, mas continuo a trabalhar bastante sobre os juízes e sobre a maneira que eles trabalham e julgam. Na verdade, eu larguei a magistratura "de julgar", mas não larguei a magistratura, como eu diria... A magistratura que continua a me interessar e à qual eu sinto pertencer ainda. 


\section{Bibliografia de Antoine Garapon}

Seguem abaixo reunidos apenas os livros publicados e organizados pelo autor, individualmente ou em coautoria, incluindo apenas as versões traduzidas para a língua portuguesa. Esta é sua produção de proa, com poucas exceções. A única que merece nota - e não constará aqui - é uma longa série de artigos curtos publicados na revista Esprit ${ }^{28}$.

GARAPON, A. Bem julgar: ensaio sobre o ritual judiciário. Lisboa: Instituto Piaget, 1999.

. Bien Juger: essai sur le rituel judiciaire. Paris: Odile Jacob, 1997.

- Crimes que não se podem punir nem perdoar. Lisboa: Instituto Piaget, 2004.

. Des Crimes qu'on ne peut ni punir ni pardonner: pour une justice internationale. Paris: Odile Jacob, 2002.

. Justice et médias: une alchimie douteuse. Paris: Fondation Saint-Simon, 1994.

. L'âne portant des reliques: essai sur le rituel judiciaire. Paris: Le Centurion, 1985.

. La Raison du moindre État: néolibéralisme et la justice. Paris: Odile Jacob, 2010.

. Le bien commun. Paris: Michalon, 1999.

. Le promesses: justice et démocratie. Paris: Odile Jacob, 1996.

. Les juges, un pouvoir irresponsable? Paris: Nicolas Philippe, 2003.

O Juiz e a democracia: o guardião de promessas. Rio de Janeiro: Revan, 2001.

. Peut-on réparer l'histoire? Colonisation, esclavage, Shoah. Paris: Odile Jacob, 2008.

28 http://www.esprit.presse.fr/ 
; ALLAIN, M.; MONGIN, O. (Org.). Kosovo: un drame annoncé. Paris: Michalon, 1999.

; ALLARD, J.; GROS, F. Les Vertus du Juge. Paris: Dalloz, 2008. 2005.

; ALLARD, J. Les Juges dans la mondialisation. Paris: Seuil,

; ALLARD, J. Os Juízes na mundialização. Lisboa: Instituto Piaget, 2006.

; GROS, F; PECH, T. Punir em democracia. Lisboa: Instituto Piaget, 2002.

; GROS, F.; PECH, T. Et ce sera justice: punir en démocratie. Paris: Odile Jacob, 2001.

; PAPADOPOULOS, I. Juger en Amérique et en France. Paris: Odile Jacob, 2003.

; PAPADOPOULOS, I. Julgar nos Estados Unidos e na França. Rio de Janeiro: Lúmen Juris, 2008.

; PERDRIOLLE, S.; BERNABÉ, B. La Prudence et I'Autorité. Juges et procureurs du XXle siècle. Paris: Odile Jacob, 2014.

; SALAS, D. (Org.). Imaginer la loi: le droit dans la littérature. Paris: Michalon, 2008.

; SALAS, D. A justiça e o mal. Lisboa: Instituto Piaget, 2000.

; SALAS, D. La Justice et le Mal. Paris: Odile Jacob, 1997.

; SALAS, D. La République pénalisée. Paris: Hachette, 1996.

; SALAS, D. Les nouvelles sorcières de Salem: Leçon d'Outreau. Paris: Seuil, 2006.

; SERVAN-SCHREIBER, P. (Org..). Deals de justice: le marché américain de l'obéissance mondialisée. Paris: PUF, 2013.

Autores convidados. 